TAPROBANICA, ISSN 1800-427X. April, 2020. Vol. 09, No. 01: pp. 50-58, pls. 19-21. (C) Research Center for Climate Change, University of Indonesia, Depok, Indonesia www.taprobanica.org

\title{
REDESCRIPTION OF Lycodon travancoricus (BEDDOME, 1870) (REPTILIA: COLUBRIDAE), AN INDIAN ENDEMIC SNAKE, WITH A REVIEW OF ITS GEOGRAPHIC RANGE
}

\author{
S. R. Ganesh ${ }^{1}$, A. A. Thasun Amarasinghe ${ }^{2,4}$ \& Gernot Vogel ${ }^{3,5}$ \\ ${ }^{1}$ Chennai Snake Park, Rajbhavan post, Chennai 600 025, Tamil Nadu, India \\ ${ }^{2}$ Research Center for Climate Change, University of Indonesia, Gd. PAU Lt. 8.5, Kampus UI, Depok 16424, \\ Indonesia \\ ${ }^{3}$ Society for Southeast Asian Herpetology, Im Sand 3, D-69115 Heidelberg, Germany \\ ${ }^{4}$ Association of Asian Herpetology (Asosiasi Herpetologi Asia), Jl. BSD Bintaro No. 88, Pondok Aren 15228, \\ Tangerang Selatan, Indonesia \\ ${ }^{5}$ Corresponding author. E-mail: Gernot.Vogel@t-online.de
}

\begin{abstract}
We redescribe the poorly-known peninsular India endemic colubrid snake Lycodon travancoricus based on its traceable syntype. We elaborate on the geographic range of the species and reveal its distribution in several disjunct hill ranges scattered across its range - the Western Ghats, the Eastern Ghats and the Central Indian Highlands. Discussions about a suggested relegation of its status as a subspecies of the widespread L. aulicus are revisited, in light of new knowledge on the species complex to which it belongs. Our perusal of extralimital records allocated to this species reveals frequent incorrect identification and provenance of specimens. Our results bolster the view that the existing diagnosis is sufficient to distinguish this species from regional congeners supporting its continued recognition as a valid species restricted to peninsular India.
\end{abstract}

Key words: distribution, Eastern Ghats, identification, Indian peninsula, syntype, Western Ghats.

\section{Introduction}

The Travancore wolf snake Lycodon travancoricus (Beddome, 1870) is a nonvenomous, nocturnal, colubrid snake occurring in the hills of peninsular India, especially the Western Ghats (Smith 1943, Whitaker 1978, Murthy 1982, 1983, Daniel 2002, Das 2002, Whitaker \& Captain 2004, Khaire 2014, Aengals et al. 2018). This species was first described as
Cercaspis travancoricus based on two syntypes (BMNH 1946.1.13.75; the second untraceable) from Attraymallay Hills, Travancore, 5,000 feet (Beddome 1870). The type locality, Travancore Hills, is a part of an ancient, rainforested, lofty mountain range, the Western Ghats, which harbours a rich endemic radiation of herpetofauna (Das 1996). Since its description this species has been recorded from a few other 
localities in the Western Ghats: Anaimalais, Nilgiris (Boulenger 1890), Tinnevellis (now Tirunelveli; Sclater 1891), Trevandrum (Ferguson 1895), Talipparamba (Boettger 1898), Cannanore (Wall 1905), Matheran (Wall 1909), Wynaad (Wall 1919) and Laccadives (now Lakshadweep, off Kerala coast; Adiyodi 1963).

Sclater (1891) was the first to list this species outside the Western Ghats-"South Arcot", (now Villupuram district, in Tamil $\mathrm{Nadu}$ ) based on specimens from the Indian Museum (now Zoological Survey of India, Kolkata) numbered "ZSI 13271, 13272". South Arcot is a part of the Eastern Ghats hill range, which is at much lower elevation, drier and discontinuous when compared to the Western Ghats. Subsequently this species was reported from other localities outside the Western Ghats: Vizagapatam (now Vishakapatnam, in Andhra Pradesh) and Jubbelpore (now Jabalpur, in Madhya Pradesh; Wall 1923). Angel (1947) lists this species from the Shevaroys, in Southern Eastern Ghats.

This species has sometimes been considered a subspecies or parapatric representative of valid sympatric congeners such as Lycodon aulicus (Linnaeus, 1758) (see Constable 1949) and $L$. striatus (Shaw, 1802) (see Sclater 1891). As a result, dubious localities like Pondicheri (Constable 1949), Hyderabad in Pakistan (Mertens 1969) and Jammu and Kashmir (see remarks in Whitaker \& Captain 2004) were added to its presumed distribution. Even recently, some authors accepted Mertens' (1969) record from Pakistan and did not consider Lycodon travancoricus as endemic to India (Sharma 2003, Khan 2006).

However, other contemporary works on Indian snakes have considered Lycodon travancoricus as a distinct species, endemic to the hills of peninsular India (Whitaker 1978, Murthy 1982, Daniel 2002, Das 2002, Whitaker \& Captain 2004, Khaire 2014, Aengals et al. 2018). Recent publications listing this species from the parts of the Eastern Ghats (Rao et al. 2004, Srinivasulu \& Das 2008, Zug 2012) have proven to be misidentified reports of $L$. aulicus (see Ganesh \& Chandramouli 2011), although several recent records from the Southern Eastern Ghats (Ganesh \& Arumugam 2016, Ganesh et al. 2018) have been verified as belonging to $L$. travancoricus. Since $L$. travancoricus has had an unstable taxonomy and consequently an unclear geographic range, we hereby take this opportunity to redescribe and diagnose this species based on its type specimen and to clarify and map its distribution range.

\section{Materials and Methods}

This study is based on examination of the traceable syntype of the species dealt with and specimens examined from collections of BMNH (Natural History Museum, London, UK), CAS (California Academy of Sciences, San Francisco, USA), FMNH (Field Museum of Natural History, Chicago, USA), NMW (Naturhistorisches Museum Vienna, Austria), MCZ (Museum of comparative Zoology, Harvard University, Cambridge, USA), and Zoological Survey of India, Kolkata, India (ZSI). Museum acronyms follow Uetz et al. (2019). We also included information on this species based on our own personal field observations. Morphometric and meristic data for species comparisons were obtained from examined specimens (see Appendix I).

We measured snout-vent length (SVL, measured from tip of snout to anterior margin of vent) and tail length (TAL, measured from anterior margin of vent to tail tip) using a twine and a ruler (least count $1 \mathrm{~mm}$ ). The following characters were measured with a digital caliper $( \pm 0.1 \mathrm{~mm})$ on the left side of the body for symmetrical characters: eye diameter (ED, horizontal diameter of eye); eye-nostril length (EN, distance between anterior most point of eye and middle of nostril); snout length (ES, distance between anterior most point of eye and snout); nostril diameter (ND, horizontal diameter of nostril); internarial distance (IN, least distance between nostrils); mandibleposterior eye distance (MPE, distance between posterior edge of mandible and posterior most edge of eye); interorbital width (IO, least distance between upper margins of orbits); head length (HL, distance between posterior edge of mandible and tip of snout); head width (HW, maximum width of head). Meristic characters were taken as follows: supralabials and infralabials (first labial scale to last labial scale bordering gape); dorsal scale rows (counted around the body from one side of ventrals to the other in three positions, on one head length behind neck, at mid body and at one head length prior to anal plate); when counting the number of ventral scales, we scored specimens according to method described by Dowling (1951). We counted subcaudal scales from first subcaudal scale to the scale before the tip of the tail.

Morphological data of this species were 
gleaned from pertinent literature (Beddome 1870, Boulenger 1890, 1893, Wall 1919, Smith 1943, Constable 1949). Distribution records were taken from the following literature (Beddome 1870, Theobald 1876, Sclater 1891, Boulenger 1894, Wall 1905, 1909, 1919, 1923, Smith 1943, Campden-Main 1968, Whitaker \& Captain 2004). Where pertinent, we also elaborate on some doubtful specimens that had caused contentious opinions on their identity or geographic range. Geographic coordinates were given in decimal degree format, rounded off to three decimal points.

\section{Taxonomy}

Lycodon travancoricus (Beddome, 1870)

(Figs. 1-6, Table 1)

Cercaspis travancoricus Beddome, 1870

Cercaspis travancorikus (sic)— Theobald 1876

Lycodon travancoricus — Boulenger 1890

Ophites travancoricus — Wall 1923

L. aulicus travancoricus - Constable 1949 part

L. travancoricus — Whitaker \& Captain 2004

Syntypes $(\boldsymbol{n}=2)$. Female, BMNH 1946.1.13.75, SVL $308 \mathrm{~mm}$, collected from Travancore, Attraymallay Hills, 5000ft [now Athirimalai, $8.776^{\circ} \mathrm{N}, 77.216^{\circ} \mathrm{E}$ in Trivandrum, Kerala, India], by R.H. Beddome; second syntype untraceable (also see Beddome 1870; Wallach et al. 2014).

Other specimens $(\boldsymbol{n}=9)$. Females, CAS 15967, SVL $340.0 \mathrm{~mm}$, collected from Ernakulam, Cochin St., India by A.W.C.T. Herre on 17 January 1941; ZSI 13695 (SVL 359.0 $\mathrm{mm}$ ), ZSI 13696 (SVL $442.0 \mathrm{~mm}$ ), collected from Piermed (3500 feet), Travancore, South India, given by Trivandrum Museum; ZSI 13396, SVL $363.0 \mathrm{~mm}$, collected from Coonoor, Nilgiris, India, by F. Daly; ZSI 17693, SVL $546.0 \mathrm{~mm}$, collected from India. Males, FMNH 217705, SVL $431.0 \mathrm{~mm}$, collected from Ponmudi, Trevandrum Dt., Kerala, India by R.F. Inger \& H.B. Shaffer on May 1982; ZSI 13694 (SVL $408.0 \mathrm{~mm}$ ) \& ZSI 13698 (SVL 463.0 $\mathrm{mm}$ ); ZSI 13531, SVL $446.0 \mathrm{~mm}$, collected from Koppa, Mysore, India, by W.M. Daly.

Diagnosis. A species of Lycodon from peninsular India, characterized by following diagnostic characters: undivided anal scale, subcaudals, whole series or in part, often undivided, loreal not in contact with eye and internasal, anterior and posterior nasals subequal, preocular reaching upper surface of head, preocular in contact with prefrontal and frontal, prefrontal in contact with postnasal, but not with supraocular, supralabials usually 9 on each side of head, snout spatulate and depressed (also see Boulenger 1890, Smith 1943, Lanza 1999).

Redescription of a syntype. Female, BMNH 1946.1.13.75, SVL $308.0 \mathrm{~mm}$, tail length 81.0 $\mathrm{mm}$; head elongate, twice as long as wide, mildly depressed, distinct from neck; snout elongate, moderate, flattened and wide in dorsal view, blunt and rounded in lateral profile, forming an oval shape, rather depressed, mildly produced anteriorly, the muzzle marginally exceeding the mentum.

Rostral shield moderate, hemispherical, distinctly visible from above, pointed posteriorly, notched ventrally, protruding beyond mental, as wide as posterior border of internasals; nostrils large, placed in a suture between anterior and posterior nasal scales; nasals divided, shorten, anterior and posterior nasals subequal in size; anterior nasal in contact with rostral and internasal dorsally, $1^{\text {st }}$ supralabial ventrally; posterior nasal in contact with internasal and prefrontal dorsally separating loreal and internasal, $1^{\text {st }}$ supralabial ventrally; internasals square-shaped; prefrontal rather large, twice as large as internasals, longer than wide, and subpentagonal, in broad contact with loreal ventrally and with preocular and frontal posteriorly, posteriorly in line with posterior border of preoculars; frontal large, subhexagonal, elongate posteriorly beyond the posterior margin of supraoculars, slightly longer than width, slightly longer than internasals and prefrontals together; supraoculars wide, elongated, subrectangular, posteriorly wider; parietals large, elongate, butterfly wing-like in shape, bordered by supraoculars, frontal, upper postocular anteriorly, anterior and upper posterior temporals, and four dorso-nuchal scales posteriorly; single loreal scale, elongate, in contact with posterior nasal anteriorly, prefrontal and preocular dorsally, post ocular ventrally, and $1^{\text {st }}-3^{\text {rd }}$ supralabials ventrally; eye large, round, larger than internasal, pupil rounded; one preocular (both sides), vertically shortened, subpentagonal, in contact with prefrontal and loreal anteriorly, prefrontal, frontal, and supraocular dorsally, and $3^{\text {rd }}$ supralabial ventrally; two postoculars (left) and three postoculars (right), subequal in size, pentagonal, upper post ocular in contact with 
supraocular, parietal, anterior temporal and lower (or middle) postocular; lower (or middle) postocular in contact with anterior temporals posteriorly; lower (left) lowest (right) postoculars in contact with $5^{\text {th }}$ supralabial ventrally; temporals $2+3$.

Supralabials 9 (on both sides), $2^{\text {nd }}-6^{\text {th }}$ larger in size, $5^{\text {th }}$ being the largest, $3^{\text {rd }}-5^{\text {th }}$ contacting the eye; $1^{\text {st }}$ supralabial triangular, in contact with rostral and both nasals anteriorly and dorsally, $2^{\text {nd }}$ supralabial with loreal dorsally, $3^{\text {rd }}$ supralabial with loreal, preocular and orbit dorsally, $4^{\text {th }}$ supralabial with orbit, $5^{\text {th }}$ supralabial with orbit and the lower postocular dorsally, $6^{\text {th }}$ supralabial with lower postocular and temporal dorsally, and $7^{\text {th }}-9^{\text {th }}$ supralabials with temporals and body scales dorsally.

Mental small, smaller than all infralabials, triangular, wider than long; first infralabial pair enlarged, elongate, and in broad contact with each other, in contact with anterior chin shield posteriorly; ten infralabials, $1^{\text {st }}-5^{\text {th }}$ in contact with first chin shield, $5^{\text {th }}$ infralabial in narrow contact with the anterior chin shield and in broader contact with the posterior chin shield; $6^{\text {th }}$ infralabial largest in size in narrow contact with posterior chin shield, $6^{\text {th }}-10^{\text {th }}$ infralabials in contact with gular scales; both two larger anterior chin shields and two smaller posterior chin shields in broad contact each other; posterior chin shields bordered posteriorly by four gular scales.

Body robust, elongate and subcylindrical of rather uniform girth; costal scales in 17-17-15 rows, all smooth and bluntly pointed; preventrals 2 , much narrower than ventral scales, not extending to full width, in contact with posterior genials; 176 ventral scales, laterally angulate; anal plate not divided.

Tail cylindrical, tapering to a fine point, fairly long (20.8\% of total length), robust and thick; 63 entire subcaudals.

Coloration. In the preserved syntype (BMNH 1946.1.13.75), dorsally dark purplish brown with faint off-white crossbars; ground colour and crossbars more intense anteriorly, obscure posteriorly; crossbars getting faint on tail, those on body more distant (inter-bar distance 6 or 7 scales) anteriorly and closer (2 scales apart) posteriorly, bifurcating laterally along the outer 1-5 scale rows, single vertebrally, across scale rows 6-9; crossbars 41 in number on the body; supra and infralabials pale white with darker speckles; underside of head white, with grey-brown scale borders and mental; venter unpatterned white.

Table 1. Morphometric (in mm) and meristic characters of Lycodon travancoricus (Beddome, 1870).

\begin{tabular}{lcc}
\hline \multirow{2}{*}{ Character } & \multicolumn{2}{c}{ L. travancoricus } \\
\cline { 2 - 3 } & females (including syntype, $n=5)$ & males $(n=4)$ \\
\cline { 2 - 2 } head length (HL) & $12.6-26.9$ & $14.9-16.4$ \\
head width (HW) & $6.6-12.5$ & $6.9-9.0$ \\
eye-snout length (ES) & $3.6-7.5$ & $4.5-4.8$ \\
eye diameter (ED) & $2.1-2.7$ & $1.7-2.2$ \\
internarial distance (IN) & $2.0-3.9$ & $2.2-2.6$ \\
interorbital width (IO) & $3.8-6.4$ & $4.4-5.8$ \\
mandible-eye distance (MPE) & $7.6-16.7$ & $9.8-10.6$ \\
tail length (TAL) & $80.0-110.0$ & $111.0-117.0$ \\
snout-vent length (SVL) & $308.0-546.0$ & $408.0-463.0$ \\
ventrals & $176-204$ & $168-177$ \\
subcaudals & $54-68$ & $67-73$ \\
supralabials & 8,9 & 9 \\
infralabials & 10 & 10 \\
costals & $17,17,15$ & $17,17,15$ \\
\hline
\end{tabular}

Variation. See Table 1.

Hemipenis. Based on FMNH 211705 and an uncollected roadkill specimen; everted; organ fairly short and thick; creamy white in preservative; bright red in life; reaching up to $4^{\text {th }}$ subcaudal scale once totally everted; unilobed, not forked at tip; lobe head as wide a long; covered with short spiky flounces on top; lateral aspect of lobe covered with longer, cursive flounces; sulcus spermaticus visible as a groove in sulcul view, centripetal in curvature; fully covered by flounces in asulcul view. 


\section{Plate 19}

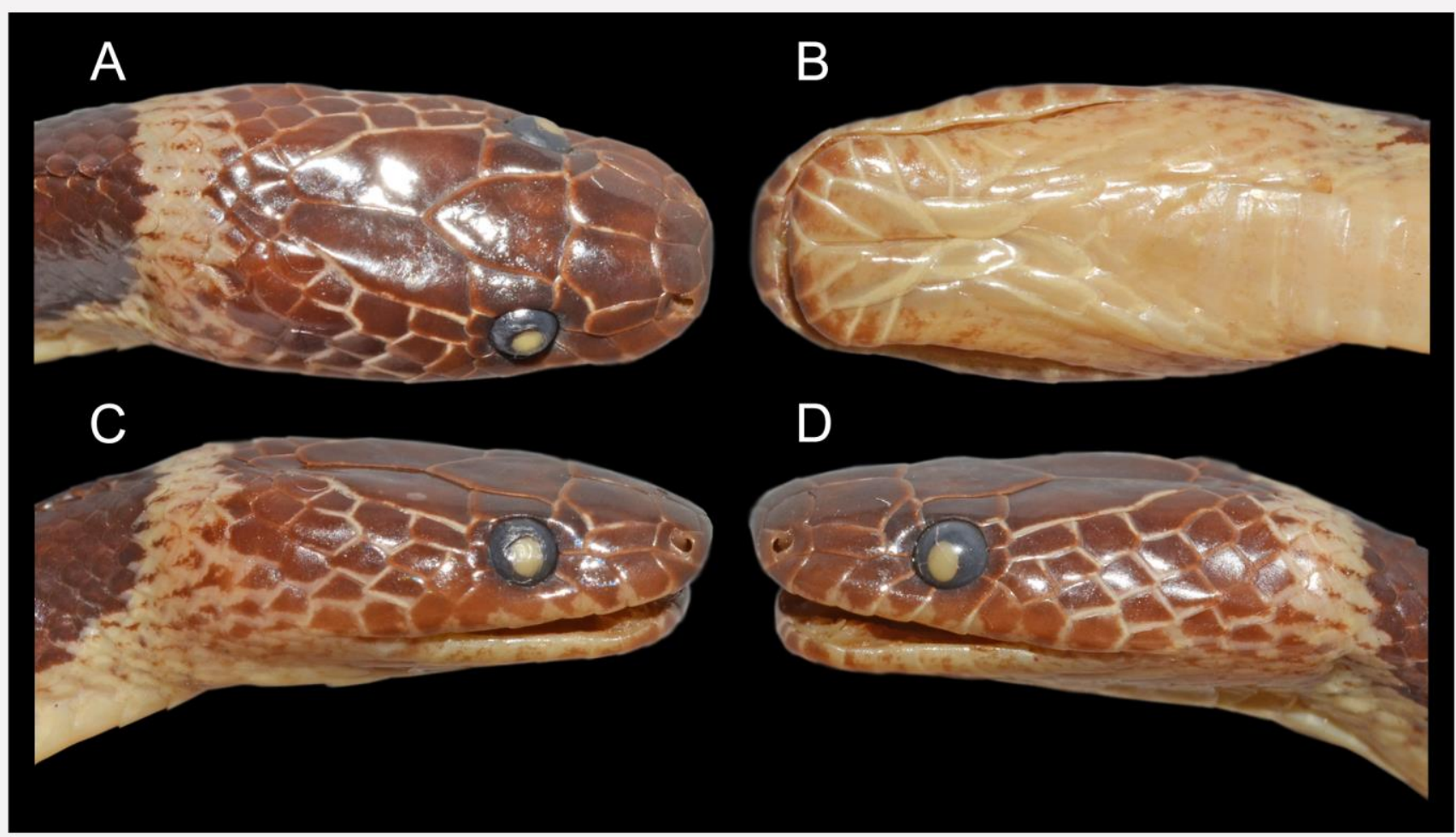

Figure 1. Head view of Lycodon travancoricus syntype (BMNH 1946.1.13.75) (A) dorsal, (B) ventral, (C, D) lateral. Photograph (C) Gernot Vogel.

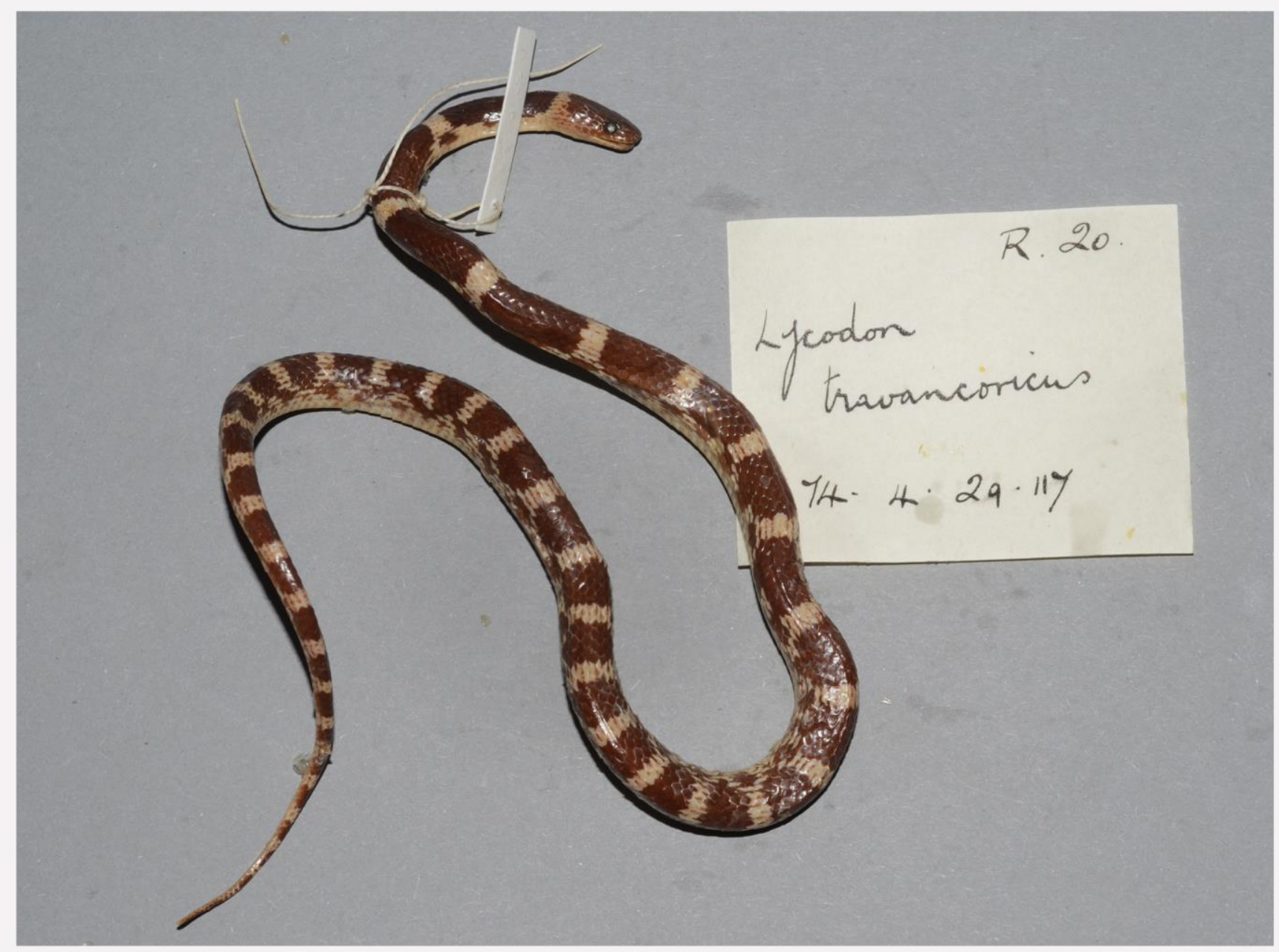

Figure 2. Dorsal full body view of Lycodon travancoricus syntype (BMNH 1946.1.13.75), SVL $308 \mathrm{~mm}$. Photograph (C) Gernot Vogel. 
Distribution. A hill species, essentially inhabiting wet rainforested mountainous tracts (Fig. 3). Most of the records are from the Western Ghats (Murthy 1981, Hutton \& David 2009, Chandramouli \& Ganesh 2010, Bhupathy \& Sathishkumar 2013, Ganesh et al. 2013, 2014, Palot, 2013, 2015, Yadav \& Yankanchi 2014, Patel et al. 2019). This species has been found from as low as $310 \mathrm{~m}$ (Inger et al. 1984) up to 1,900 m a.s.l. (Roux 1928, Wall 1919).

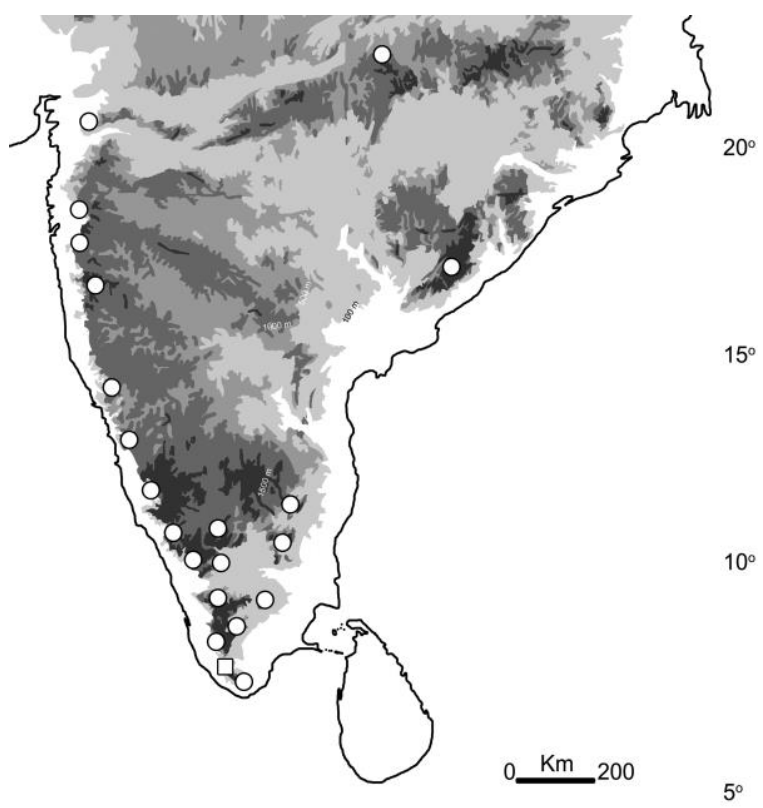

Figure 3. Distribution map of Lycodon travancoricus (circles). The type locality is marked with a square symbol. Map (C) A.A. Thasun Amarasinghe

Natural History. A nocturnal species. Resting individuals were found inside rotten logs and under stones (see Beddome 1870) during daytime. Active individuals have been seen particularly during rainy nights, often foraging on Ghat roads. Wall (1919) recorded animals such as bush frogs (Raorchestes sp., Pseudophilautus sp.), skinks (Riopa sp., Eutropis sp.), agamid lizards (Psammophilus sp.) and geckos in gut-content of snakes from the Nilgiri-Waynad. Based on personal observations, young animals $(<150 \mathrm{~mm})$ have been observed during late May to June in Cardamom Hills and the High Range. The species is often encountered near human settlements, such as tea estate bungalows (Whitaker \& Captain 2004). When disturbed or restrained, individuals were seen hiding their head tucked inside the body coils (Fig. 4D). This species is known to indulge in death-feigning behavior, as it turns upside down, except for the head peeping out looking at the potential adversary (Fig. 4D). This species faces anthropogenic threats such as roadkills (Ganesh \& Arumugam 2015) as well as man-snake conflict situations, being killed by people out of fear, particularly as it is often mistaken for Bungarus sp., the venomous kraits (Balakrishnan 2010).

\section{Discussion}

Beddome (1870) mentioned basing his description on two specimens (syntypes), one with all subcaudals entire and the other one with a few scales towards the tail tip divided. He gave the subcaudal count as 66 , for the specimen that had all the subcaudals entire. This is the syntype specimen that we redescribed here and its subcaudal count turns out to be 61 according to our count. Beddome (1870) did not furnish the ventral scale count of both types in his original description. Boulenger (1890) gave a range of ventral counts, as 178-202. The lower margin of this range (178) is most likely that of the syntype here redescribed. Our count was 176, excluding two preventrals. Beddome (1870) also mentions the supralabials to be 8 , where subsequent authors and ourselves found it to be 9 (Boulenger 1890, Smith 1943, and this work).

Boulenger (1890) diagnosed $L$.
travancoricus based on (i) undivided anal scale, (ii) depressed and spatulate snout. Later, Smith (1943) identified two more head scalation characters: (iii) anterior and posterior nasal scales subequal, (iv) loreal not touching eye and internasal. Beddome (1870) did not elaborate much on these subtle head scalation features. However, he mentioned the "preocular reaching the upper surface of head and touching the postfrontal and vertical [scales]." In fact the preocular touches prefrontal and frontal (Smith 1943, and this work). While Boulenger (1890) states that the preocular usually is in contact with the frontal, Smith (1943) emphasizes on the separation of the loreal from the eye and internasal.

Constable (1949) examined some specimens attributed to $L$. aulicus in the MCZ collections. $\mathrm{He}$ concluded that because the diagnostic characters that purportedly separate $L$. travancoricus are also present in some $L$. aulicus, they both should be regarded as subspecies rather than species. We studied the specimens that Constable (1949) used for relegating the status of $L$. travancoricus that were referred to as intergrades between the two taxa [MCZ R2232 Pondicheri (Fig. 5), MCZ 
R3877, MCZ R4783 both from Madras]. Constable (1949) based his observations of these atypical specimens (from Pondicheri and Madras) of the L. aulicus complex with head scalation configuration and undivided anal scale, very similar to that of $L$. travancoricus. Specimens from Madras (collected by Beddome, British Museum exchange) turned out to be $L$. aulicus while that from Pondicheri (Paris Museum exchange) turned out to be $L$. anamallensis according to our identification.

As for its report from Hyderabad $\left(25.401^{\circ} \mathrm{N}\right.$, $\left.68.361^{\circ} \mathrm{E}\right)$ in Sindh, W. Pakistan, Mertens (1969) remarked that neither Konieczny nor Minton met with this snake in West Pakistan. Mertens's record refers further to Minton (1966) who reported $L$. travancoricus from Pakistan based on a museum specimen. This specimen, FMNH 42211 (Fig. 6), is labelled as Lycodon travancoricus with locality data "India [British India], Sind, Hyderabad College garden" Coll. James A. Peters, on $15^{\text {th }}$ September 1944. Minton quotes J.A. Peters of recalling that "it was given to me by Tulyani or his colleagues...I would not vouch for it as strongly as I would have collected it myself". Thus there is clear ambiguity in the provenance of FMNH 42211. We examined this specimen and opine that it is closer to $L$. travancoricus than to any other South Asian taxa, but differs in having lower ventral count (162). Thus FMNH 42211 is outside the known morphological and geographical boundaries of $L$. travancoricus. As its origin is doubtful, pending wild sightings from Pakistan, $L$. travancoricus must be considered as endemic to peninsular India.

Both misidentification (in case of $\mathrm{MCZ}$ R2232 from Pondicheri) and incorrect provenance claim (in case of FMNH 42211 from Sindh) have resulted in the problems associated with $L$. travancoricus. In the first case (from Pondicheri), the previously suspected misidentification has been confirmed. In the second case (from Sindh) as the specimen involved is an ill-preserved one with incomplete tail, and further studies on the said population are needed to resolve its identity. The genus Lycodon is poorly-known taxonomically, as new species continue to be described from India (Mukherjee \& Bhupathy 2007), as well as from other countries [Vogel \& David (2019), Janssen et al. (2019) and references therein]. Though discovered and described in 1870 by R.H. Beddome (Ganesh 2010), this species has not yet been genetically sequenced till now, and an attempt to do so from an old, museum specimen proved futile (Ruane \& Austin 2017). It cannot be ruled out that there may be cryptic diversity in this complex, judging by its wide, disjunct distribution. It is hoped that the redescription of the syntype of Lycodon travancoricus will alleviate these fluxes in its taxonomy and distribution, aiding in its unambiguous identification and thereby facilitating to map its proper geographic range, by future workers.

\section{Acknowledgements}

We thank the authorities of the Tamil Nadu Forest Department for permitting and facilitating field surveys to SRG. SRG thanks the Executive Chairman and the Board of Trustees, of the Chennai Snake Park Trust, for the support and encouragements. Also we thank Patrick Campbell, David Gower (BMNH), Robert C. Drewes and Jens V. Vidum (CAS, USA), Alan Resetar (FMNH, USA), Jose Rosado and James Hanken (MCZ, USA) and Silke Schweiger and Georg Gassner (NMW) for facilitating examination of specimens to $\mathrm{GV}$; and the former Director, K. Venkataraman (ZSI) for granting research permission to AATA. In particular, AATA thanks K. Chandra (Director) K.C. Gopi, K.A. Subramanian, K. Deuti, S. Raha, P.G.S. Sethy, P. Bag, and S. Debnath for assisting while examining collections in ZSI. AATA Jatna Supriatna and the staff of the Research Center for Climate Change, University of Indonesia is acknowledged for their support. Ivan Ineich (Muséum national d'Histoire naturelle, Paris), Romulus Whitaker (Madras Crocodile Bank), Philip Bowles (IUCN), and an anonymous reviewer are acknowledged for valuable comments and reviewing the manuscript. Finally, we thank S.R. Chandramouli for kindly sharing his photograph, and the Madras Crocodile Bank Trust (India) for facilitating perusal of reference books in their library holdings.

\section{Literature cited}

Adiyodi, K.G. (1963). First record of Beddome's wolf snake Lycodon travancoricus (Beddome) from the Laccadive Archipelago. Journal of the Bombay Natural History Society, 60 (2): 261-262.

Aengals, R., V.M.S. Kumar, M.J. Palot, and S.R. Ganesh (2018). A Checklist of Reptiles of India. Zoological Survey of India, Kolkata (epublication): $35 \mathrm{pp}$.

Angel, F. (1947). Liste des reptiles et amphibiens 


\section{Plate 20}
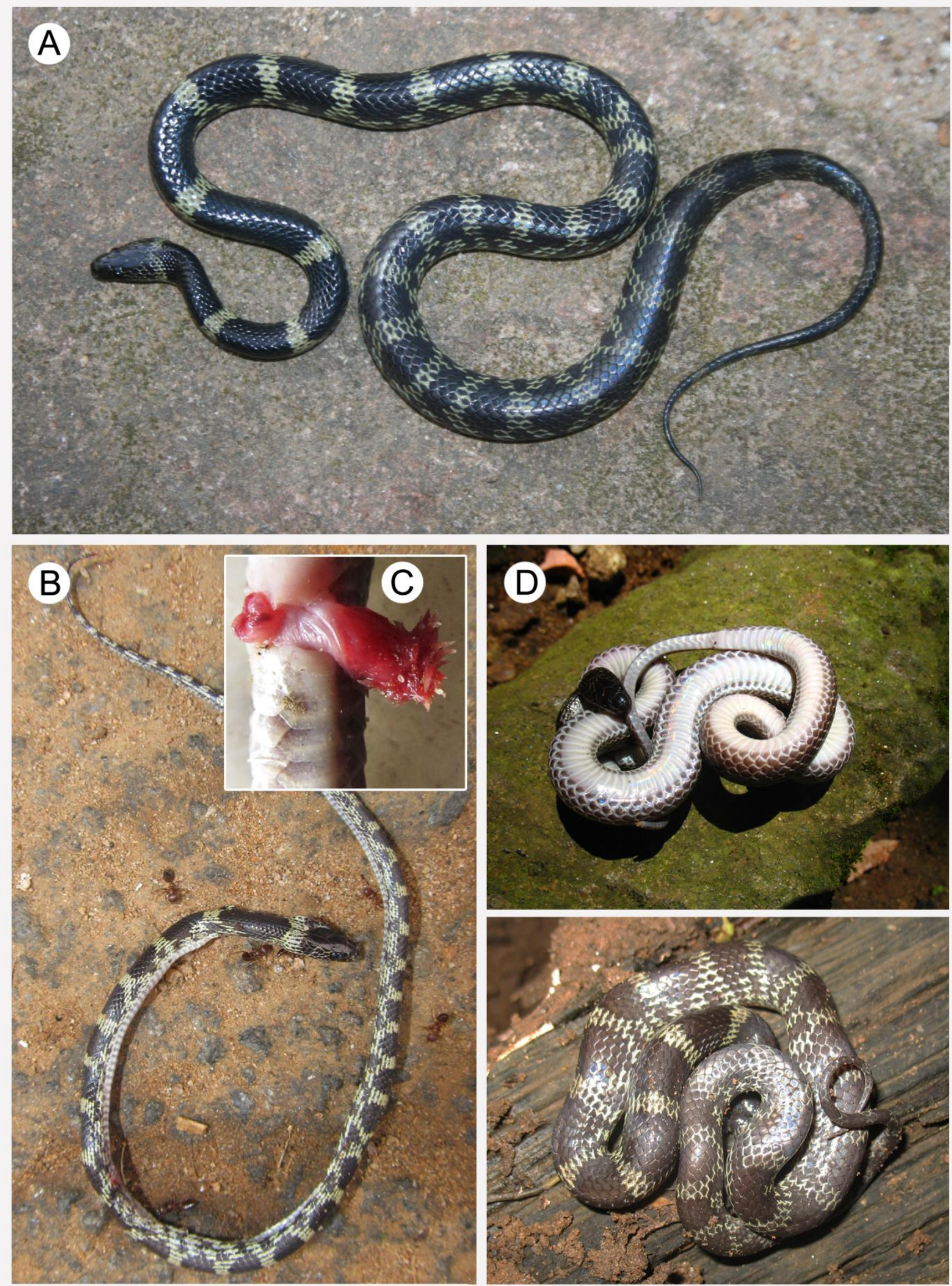

Figure 4. An adult Lycodon travancoricus from (A) the type locality (in life, not collected). Photograph (C) S.R. Chandramouli; (B) Yercaud, Tamil Nadu, India (a road kill, not collected); (C) partially everted hemipenis; and (D) Cardamom Hills, Tamil Nadu, India (not collected), shows death feigning (above), and hiding posture when disturbed (below). Photograph (C) S.R. Ganesh 


\section{Plate 21}

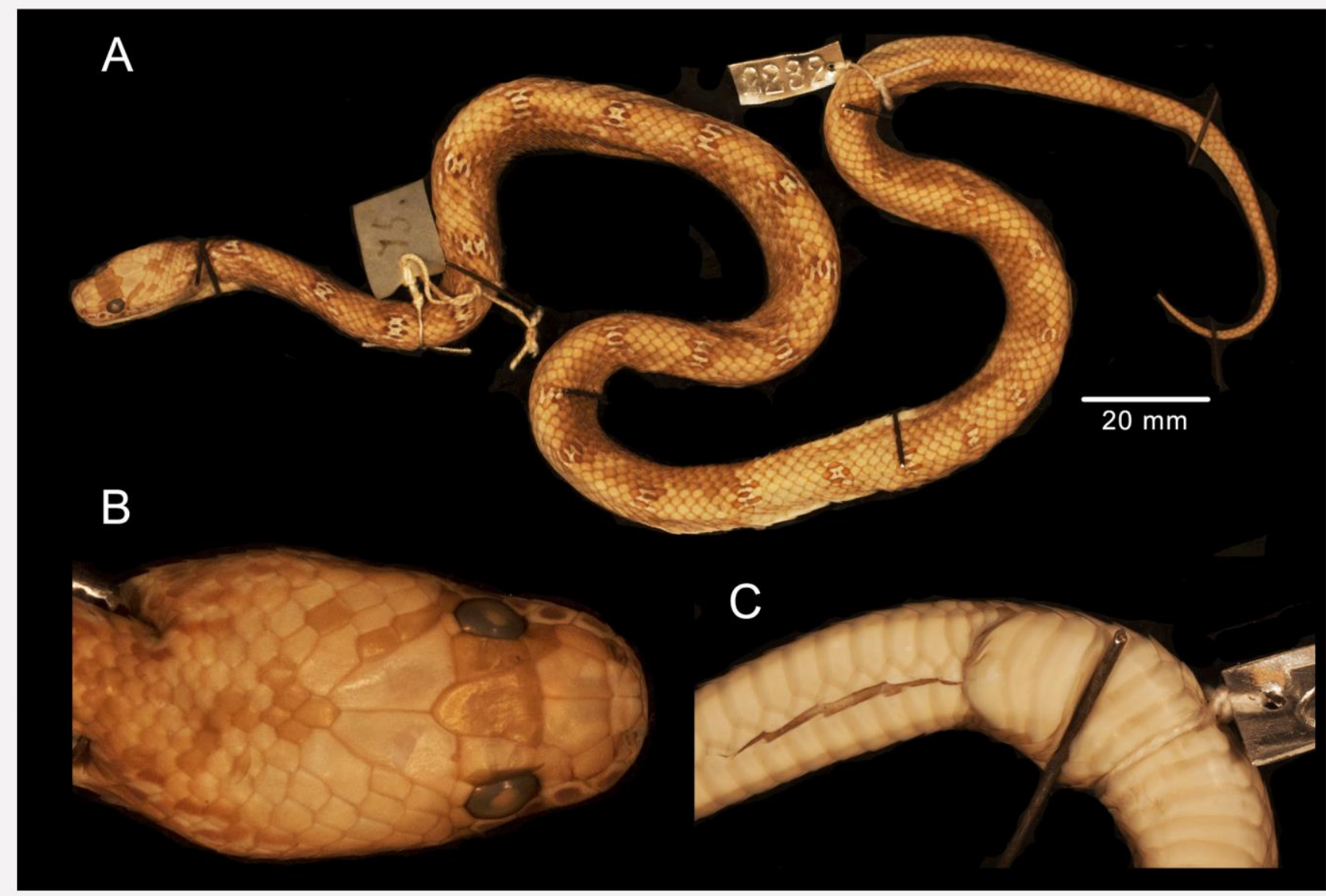

Figure 5. Lycodon anamallensis (MCZ R2232), (A) the specimen used by Constable (1949) to relegate Lycodon travancoricus as a subspecies; (B) dorsal head, and (C) anal area. Photograph (C) Jose Rosado \& James Hanken.

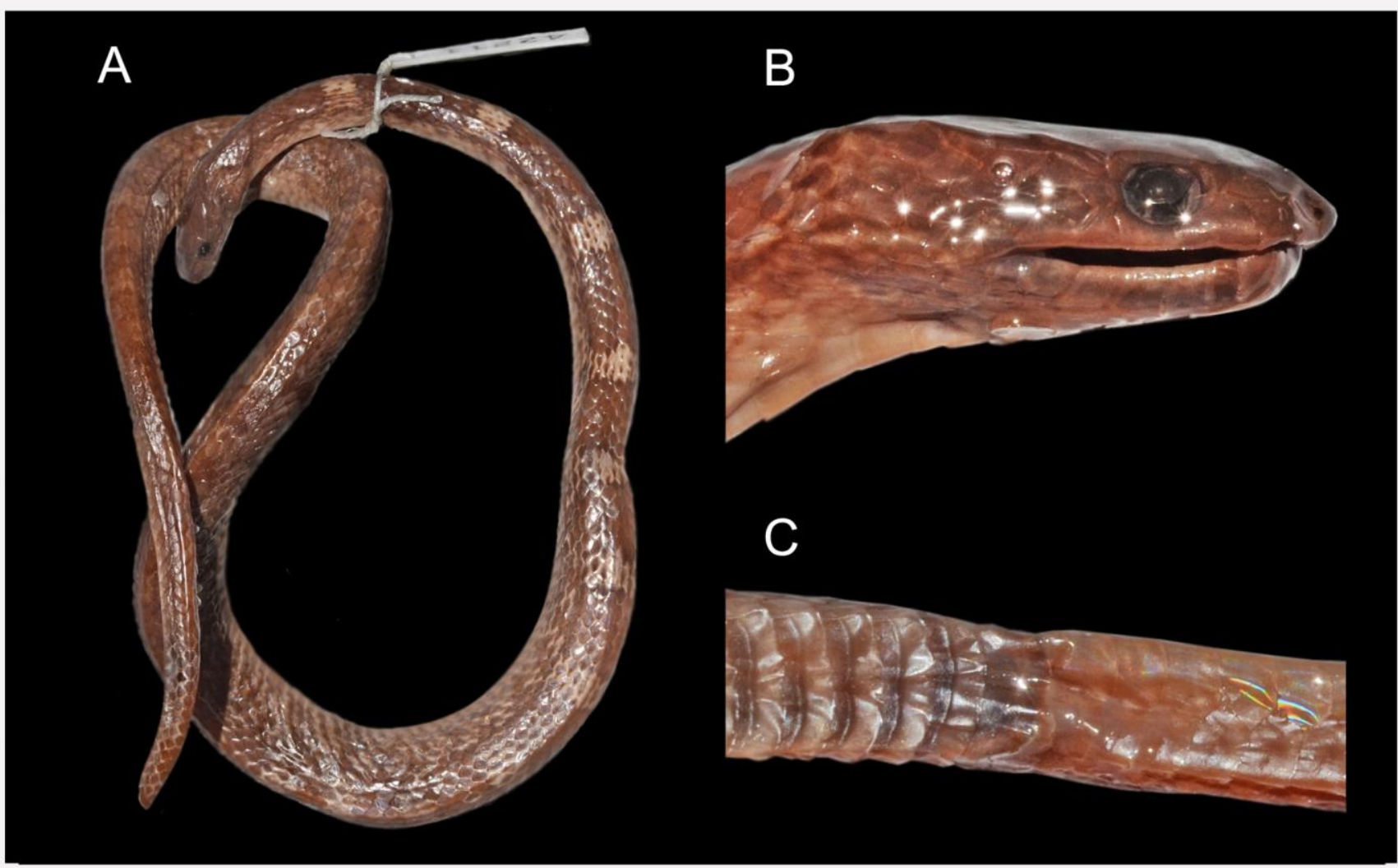

Figure 6. Lycodon sp. (FMNH 42211) (A) the specimen used by Minton (1966) to include Pakistan (Hyderabad, Sindh) into the geographic range of Lycodon travancoricus, unknown provenance; (B) lateral head, and (C) anal area. Photograph (C) Gernot Vogel. 
de l'Inde envoyés au Muséum par M. le Dr. K. Lindberg. Bulletin du Muséum d'Histoire Naturelle (Paris), Sér. 2, 19 (1): 57-59.

Balakrishnan, P. (2010). An education programme and establishment of a citizen scientist network to reduce killing of non-venomous snakes in Malappuram district, Kerala, India. Conservation Evidence, 7 (1): 9-15.

Beddome, R.H. (1870). Descriptions of new reptiles from the Madras Presidency. Madras Monthly Journal of Medical Sciences, II: 169176.

Boettger, O. (1892). Listen von Kriechtieren und Lurchen aus dem tropischen Asien u. aus Papuasien. Bericht des Offenbacher Vereins für Naturkunde, 1892: 65-164.

Boettger, O. (1898). Katalog der ReptilienSammlung im Museum der Senckenbergischen Naturforschenden Gesellschaft in Frankfurt am Main. II. Teil. (Schlangen). Druck von Gebruder Knauer, Frankfurt: 160 pp.

Boulenger, G.A. (1890). Fauna of British India, including Ceylon and Burma. Reptilia and Batrachia. Taylor and Francis, London: 541 pp.

Boulenger, G.A. (1894). Catalogue of the Snakes in the British Museum (Natural History). Volume II, Containing the Conclusion of the Colubrida Aglypha. British Museum of Natural History, London: 382 pp.

Bhupathy, S. and N. Sathishkumar (2013). Status of reptiles in Meghamalai and its environs, Western Ghats, Tamil Nadu, India. Journal of Threatened Taxa, 5 (15): 4953-4961.

Campden-Main, S.M. (1968). Index to the scientific names in "A popular treatise on the Common Indian Snakes" by Frank Wall 19051919. Smithsonian Herpetological Information Service, 13: 1-7.

Chandramouli, S.R. and S.R. Ganesh (2010). Herpetofauna of southern Western Ghats, India - Reinvestigated after decades. Taprobanica, 2 (2): 72-85.

Constable, J.D. (1949). Reptiles from the Indian peninsula from the Museum of Comparative Zoology. Bulletin of the Museum of Comparative Zoology, 103 (2): 59-159.

Daniel, J.C. (2002). The Book on Indian Reptiles and Amphibians. Bombay Natural History Society \& Oxford University Press: 248 pp.

Das, I. (1996). Biogeography of the Reptiles of South Asia. Krieger Publishing Company, Florida: $87 \mathrm{pp}$.

Das, I. (2002). A Photographic guide to Snakes and other Reptiles of India. New Holland Publishers, London: 144 pp.
Ferguson, S.H. (1895). List of snakes taken in Travancore from 1888 to 1895. Journal of the Bombay Natural History Society, 10 (1): 6877.

Ganesh, S.R. (2010). Richard Henry Beddome and South India's Herpetofauna - a tribute on his centennial death anniversary. Cobra, 4: 1-11.

Ganesh, S.R. and S.R. Chandramouli (2011). Report of some noteworthy specimens and species of herpetofauna from Southeast India. Taprobanica, 3 (1): 5-10.

Ganesh, S.R., S.R. Chandramouli, R. Sreekar, and P.G. Shankar (2013). Reptiles of the Central Western Ghats, India - A reappraisal and revised checklist, with emphasis on the Agumbe Plateau. Russian Journal of Herpetology, 20 (3): 181-189.

Ganesh, S.R., S. Bhupathy, P. David, N. Sathishkumar, and G. Srinivas (2014). Snake Fauna of High Wavy Mountains, Western Ghats, India: Species Richness, Status, and Distribution Pattern. Russian Journal of Herpetology, 21 (1): 53-64.

Ganesh, S.R. and M. Arumugam (2015). Microhabitat use and abundance estimates of understory herpetofauna in the highlands of southern Eastern Ghats, India, with observations on road kill mortalities. Asian Journal of Conservation Biology, 4 (2): 143150.

Ganesh, S.R. and M. Arumugam (2016). Species richness of montane herpetofauna of southern Eastern Ghats, India: a historical resume and a descriptive checklist. Russian Journal of Herpetology, 23 (1): 7-24.

Ganesh, S.R. and G. Vogel (2018). Taxonomic reassessment of the Common Indian Wolf Snakes Lycodon aulicus (Linnaeus, 1758) complex (Squamata: Serpentes: Colubridae). Bonn zoological Bulletin, 67 (1): 25-36.

Ganesh, S.R., A. Kalaimani, P. Karthik, N. Baskaran, R. Nagarajan et al. (2018). Herpetofauna of Southern Eastern Ghats, India, II; from Western Ghats to Coromandel Coast. Asian Journal of Conservation Biology, 7 (1): $28-45$.

Hutton, A.F. and P. David (2009). Note on a collection of snakes from South India, with emphasis on the snake fauna of the Meghamalai Hills (High Wavy Mountains). Journal of the Bombay Natural History Society, 105 (3): 299-316.

Inger, R.F, H.B. Shaffer, M. Koshy, and R. Bakde (1984). A report on a collection of amphibians and reptiles from the Ponmudi, Kerala, South India. Journal of the Bombay Natural History Society, 81 (3): 551-570. 
Janssen, H.Y., C.T. Pham, H.T. Ngo, M.D. Le, T.Q. Nguyen et al. (2019) A new species of Lycodon Boie, 1826 (Serpentes, Colubridae) from northern Vietnam. ZooKeys, 875 (1): $1-29$.

Khaire, N. (2014). Indian Snakes: a field guide, Jyotsna Prakashan, Pune: 160 pp.

Khan, M.S. (2003). Key and checklist to the snakes of Pakistan with special reference to the venomous snakes. Pakistan Journal of Zoology, Sup. 1, 1-53.

Khan, M.S. (2006). Amphibians and reptiles of Pakistan. Kreiger Publications. Malabar, Florida: $311 \mathrm{pp}$.

Lanza, B. (1999). A new species of Lycodon from the Philippines, with a key to the genus (Reptilia Serpentes Colubridae). Tropical Zoology, 12 (1): 89-104.

Mertens, R. (1969). Die Amphibien und Reptilien West-Pakistans. Stuttgarter Beiträge zur Naturkunde, 197: 1-96.

Minton, S.A., Jr. (1966). A contribution to the herpetology of West Pakistan. Bulletin of the American Museum of Natural History, 134 (2): 27-184.

Mukherjee, D. and S. Bhupathy (2007). A new species of wolf snake (Serpentes: Colubridae: Lycodon) from Anaikatti Hills Western Ghats, Tamil Nadu, India. Russian Journal of Herpetology, 14 (1): 21-26.

Murthy, T.S.N. (1981). Reptiles of the Silent Valley and New Amarambalam area, Kerala. The Snake, 13: 42-52.

Murthy, T.S.N. (1982). A contribution to the ophiology of Western Ghats, India. The Snake, 14: 50-56.

Murthy, T.S.N. (1983). Some recent records of sankes [sic] from Western Ghats, India. Indian Journal of Zootomy, 24 (1): 77-80.

Murthy, T.S.N. and R. Aengals (2008). Checklist of the reptiles of the Eastern Ghats, India. Cobra, 2 (1): 7-12.

Palot, M.J. (2013). Reptilia. In: K. Venkataraman, A. Chattopadhyay, and K.A. Subramanian (eds.), Endemic Animals of India (Vertebrates). Zoological Survey of India, Kolkata: $235 \mathrm{pp}$.

Palot, M.J. (2015). A checklist of reptiles of Kerala, India. Journal of Threatened Taxa, 7 (13): 8010-8022.

Patel, H. and R. Vyas (2019). Reptiles of Gujarat, India: Updated Checklist, Distribution, and Conservation Status. Herpetology Notes, 12: 765-777.

Patel, H., R. Vyas, and P. Vaghashiya (2019). On the distribution of Ahaetulla laudankia Deepak, Narayanan, Sarkar, Dutta \&
Mohapatra, 2019 and Lycodon travancoricus (Beddome, 1870) (Squamata, Colubridae) from Gujarat, India. Check List, 15 (6): 10451050.

Rao, K.T., H.V. Ghate, M. Sudhakar, S.M.M. Javed, and I.S.R. Krishna (2004). Herpetofauna of Nallamalai hills, with eleven new records from the region including ten new records for Andhra Pradesh. Zoo's Print Journal, 20 (1): 1737-1740.

Roux, J. (1928). Reptiles et amphibiens de l'Inde méridionale. Revue Suisse de Zoologie, 35 (21): 439-471.

Ruane, S. and C.C. Austin (2017). Phylogenomics using formalin-fixed and $100+$ year-old intractable natural history specimens. Molecular Ecology Resources, 17 (5): 1003-8.

Sclater, W.L. (1891). Notes on a collection of snakes in the Indian Museum with description of several new forms. Journal of the Asiatic Society of Bengal, 9 (2): 230-249.

Sharma, R.C. (2003). Fauna of India. Vol. III Serpentes. Zoological Survey of India, Kolkata, India: 410 pp.

Smith, M.A. (1943). Fauna of British India including Ceylon and Burma. Vol - III Serpentes. Taylor \& Francis, London: 583 pp.

Srinivasulu, C. and I. Das (2008). The herpetofauna of Nallamala hills, Eastern Ghats, India: An annotated checklist, with remarks on nomenclature, taxonomy, habitat use, adaptive types and biogeography. Asiatic Herpetological Research, 11: 110-131.

Theobald, W. (1876). Descriptive catalogue of the reptiles of British India. Thacker Spink and Co., India: 238 pp.

Vogel, G. and P. David (2019). A new species of the Lycodon fasciatus complex from the Khorat Plateau, eastern Thailand (Reptiles, Squamata, Colubridae). Zootaxa, 4577 (3): 515-528.

Wall, F. (1905). Notes on the snakes collected in Cannanore from $5^{\text {th }}$ November 1903 to $5^{\text {th }}$ August 1904. Journal of the Bombay Natural History Society, 16 (2): 292-317.

Wall, F. (1909). Notes on a collection of snakes from Matheran. Journal of the Bombay Natural History Society, 19 (3): 756-757.

Wall, F. (1919). Notes on a collection of snakes made in the Nilgiri Hills and the adjacent Wynaad. Journal of the Bombay Natural History Society, 26 (2): 552-584.

Wall, F. (1923). Hand-list of snakes of the Indian empire. Journal of the Bombay Natural History Society, 29 (2): 598-632.

Wallach, V., K.L. Williams, and J. Boundy (2014). Snakes of the World: A Catalogue of Living 
and Extinct Species. CRC Press, Taylor \& Francis Group, Florida: 1237 pp.

Whitaker, R. (1978). Common Indian Snakes: A Field Guide. MacMillan Press, Delhi: 154 pp.

Whitaker, R. and A. Captain (2004). Snakes of India - the field guide. Draco Books, Chengelpet, South India: 481 pp.

Yadav, O.V. and S.R. Yankanchi (2014). Preliminary study of herpetofaunal diversity in Radhanagari Wildlife Sanctuary (WLS), Kolhapur, Maharashtra, India. Biolife, 2: 1154-1159.

Appendix I. Other specimens examined Specimens labeled as Lycodon travancoricus, but re-identified here as other congeners: Lycodon anamallensis (2 ex.): India: Malabar: NMW 21707; Pondicheri: MCZ R2232. Lycodon aulicus (2 ex.): India: Madras: MCZ R3877, 4783.

Lycodon sp. (1 ex.): Pakistan: Hyderabad, Sindh: FMNH 42211.
Zug, G.R. (2012). Data resources for Tropical Asian dry forest Amphibians and Reptiles. Smithsonian Herpetological Information Service, Washington DC, No. 141: 25 pp. 
- blank page -

TAPROBANICA VOL. 09: NO. 01 